\title{
Sağlıklı Genç Bireylerde Kognitif Görevle Yapılan Egzersizlerin Kognitif Fonksiyonlara, Duygu Durumuna ve Yaşam Kalitesine Etkisi*
}

\author{
Fatma Eda YENİÇERİ** ${ }^{* *}$ Miray BUDAK ${ }^{* * *}$
}

\section{$\ddot{\mathbf{O z}}$}

Amaç: Günümüzde artan teknolojiyle birlikte sağllklı genç bireylerde, fiziksel aktivite düzeylerindeki azalmadan kaynaklı, kognitif durumlarında bozulma, duygu durumlarında değişiklikler ve yaşam kalitelerinde azalma görülmektedir. Kognitif görevle yapılan egzersizler bireylerin sağlık koşullarını iyileştirmektedir. Bu çalışmanın amacı sağlıklı genç bireylerde kognitif görevle yapılan denge egzersizlerinin, kognitif durum, duygu durumu ve yaşam kalitesine etkilerini incelemektir.

Yöntem: Bu çalışmaya dâhil edilme kriterlerini sağlayan 18-30 yaş aralığındaki 50 sağlıklı genç birey dâhil edildi. Bireyler randomize olarak kognitif görevli egzersiz (Grup 1) (n=25) ve sadece egzersiz (Grup 2) (n=25) grubuna ayrıldı. Bireylere günde 1 seans, haftada 3 gün olmak üzere 6 hafta boyunca egzersiz verildi. Grup 1'e aerobik egzersiz ve denge egzersizlerine ilaveten kognitif görev verildi. Grup 2'deki bireylere sadece aerobik egzersiz ve denge egzersizleri yaptırıldı. Bireyler uygulama öncesinde ve bitiminde kognitif durum (Stroop Testi, Sözel Akıcılık Testi, Sayı

\section{Özgün Araştırma Makalesi (Original Research Article)}

Geliş / Received: 16.06 .2020 \& Kabul / Accepted: 16.10 .2020

DOI: https://doi.org/10.38079/iqusabder.753667

* Bu çalışma, Fatma Eda YENIÇERİ’nin İstanbul Medipol Üniversitesi, Sağllk Bilimleri

Enstitüsü, Fizyoterapi ve Rehabilitasyon Yüksek Lisans Programı'nda Dr. Öğr. Üyesi Miray BUDAK danışmanlığında hazırladığı ve 2019 yılında kabul edilen "Sağlıklı Genç Bireylerde Kognitif Görevle Yapılan Denge Egzersizlerinin Motor ve Kognitif Fonksiyonlara Etkisi” başlıklı yüksek lisans tezinden üretilmiştir.

${ }_{* * *}^{*}$ Arş. Gör., İstanbul Gelişim Üniversitesi, Sağlık Bilimleri Yüksekokulu, Fizyoterapi ve Rehabilitasyon Bölümü, İstanbul, Türkiye, E-posta: eedayeniceri@gmail.com ORCID https://orcid.org/o000-0002-5989-9589

**** Dr. Ö̆̆r. Üyesi, İstanbul Medipol Üniversitesi, Sağlık Bilimleri Fakültesi, Ergoterapi Bölümü, İstanbul, Türkiye, E-posta: mbudak@medipol.edu.tr ORCID https://orcid.org/o000-0003$\underline{0552-8464}$ 
Menzili Testi), duygu durumu (Depresyon Anksiyete Stres Ölçeği (DASÖ)) ve yaşam kalitesi (Kısa Form 36 (SF-36)) değerlendirildi.

Bulgular: Egzersiz sonrası değerlendirmelerde Grup 1'de tüm kognitif testlerde ve SF-36 mental sağllk alt parametresinde, Grup 2'de tüm kognitif testlerde ve DASÖ depresyon alt parametresinde istatistiksel olarak anlamlı fark bulundu $(\mathrm{p}<0,05)$. Gruplar arası değerlendirmede kognitif testlerden sözel akıcılık testinde ve SF-36 mental sağlı alt parametresinde Grup 1 lehine istatistiksel olarak anlamlı fark bulundu $(\mathrm{p}<0,05)$.

Sonuç: Sağlıklı genç bireylerde, hem sadece egzersiz hem de kognitif görevle yapılan egzersizlerin kognitif fonksiyonlar üzerinde etkili olduğu görüldü. Kognitif görevle yapılan egzersizlerin sağlıklı genç bireylerin kognitif durum ve yaşam kaliteleri üzerinde etkili olduğu sonucuna ulaşıldı. Uygulanan egzersizlerin sağlıklı genç bireylerde özellikle kognisyon ve duygu durumu üzerine etkisinin daha iyi anlaşılabilmesi için, objektif nitelikteki çalışmalara ihtiyaç duyulduğu düşünülmektedir.

Anahtar Sözcükler: Egzersiz, kognitif görev, kognisyon, depresyon, yaşam kalitesi.

\title{
The Effect of Exercises with Cognitive Task on Cognitive Functions, Emotional Status and Quality of Life on Healthy Young Individuals
}

\begin{abstract}
Aim: Nowadays, with the increasing technology, there is a deterioration in cognitive states, changes in emotional states and a decrease in quality of life in healthy young individuals due to the decrease in physical activity levels. Exercises with cognitive tasks improve the health conditions of individuals. The aim of this study is to examine the effects of aerobic and balance exercises with the cognitive task on cognition, mood and quality of life in healthy young adults.

Methods: Fifty healthy young adults between the aged 18-30 who meet the inclusion criteria were included in the study. Individuals were randomly divided into 2 groups as exercise with the cognitive tasks (Group 1) ( $n=25)$ and exercise only (Group 2) $(n=25)$. Exercises were performed 1 session daily, 3 days a week over 6 weeks. Aerobic and balance exercises with the cognitive tasks were performed in Group 1. Only aerobic and balance exercises were performed in Group 2. Individuals were evaluated for cognition (Stroop Test, Verbal Fluency Test, Number Range Test), mood (Depression Anxiety Stress Scale (DASS)) and quality of life (Short Form 36 (SF-36)) before and after the exercises.
\end{abstract}

Results: A statistically significant difference was found in all cognitive tests and SF-36 mental health sub-parameter in Group 1 and in all cognitive tests and DASS depression sub-parameter in Group 2 within-group evaluations $(\mathrm{p}<0,05)$. Between-groups evaluations, it was found that a 
statistically significant difference in the Verbal Fluency Test and SF-36 mental health subparameter in favor of Group $1(\mathrm{p}<0,05)$.

Conclusion: In healthy young adults, both exercises and exercises with the cognitive tasks were found to be effective on cognitive functions. It was concluded that aerobic and balance exercises with cognitive tasks are effective on healthy young adults' cognition and quality of life. It is thought that objective studies are needed in order to better understand the effects of exercises on cognition and mood in healthy young adults.

Keywords: Exercise, cognitive task, cognition, depression, quality of life.

\section{Giriş}

İnsan yaşamında kognitif gelişim, duygu durumu ve yaşam kalitesi birbiriyle yakından ilgilidir. Kognitif fonksiyonlar, yirmili yaşların başlarında en yüksek seviyeye ulaşır. Ancak yaş, cinsiyet, eğitim süreci, alkol ve sigara, sistemik hastalıklar, depresyon, sedanter yaşam, sosyal aktivite ve meslek gibi sağlı̆̆ı tehdit eden risk faktörleri kognitif gelişim, duygu durumu ve yaşam kalitesini olumsuz yönde etkileyebilmektedir ${ }^{1}$. Son yllarda küreselleşme ve teknolojik değissiklikler, fiziksel olarak zorlu görevlerden, bilgiye dayalı çalışmalara veya gelişmiş bir bilişsel fonksiyon talep eden zihinsel aktiviteye doğru aşamalı bir geçişi desteklemiştir. Özellikle artan teknoloji kullanımıyla birlikte sağlıklı genç bireyler sedanter yaşam koşullarına yönelmektedir. Sedanter yaşam, çok düşük enerji harcaması gerektiren uzanmış, oturmuş veya yatar pozisyondaki belirli faaliyetleri ifade eder ve gelişmiş ve gelişmekte olan ülkelerde oldukça sık görülmektedir² ${ }^{2}$

Fiziksel aktivite, fiziksel ve psikolojik refahı artırmada önemli bir role sahiptir3. Bununla birlikte, dünya çapındaki yetişkinlerin üçte biri mevcut fiziksel aktivite önerisine (haftalık 150 dakikalık orta yoğunluklu fiziksel aktivite) ulaşmamaktadır'. Fiziksel olarak inaktif olan bireyler, uyanık kalma sürelerinin ortalama \%55'ini sedanter olarak geçirirler. Sedanter bireyler mevcut fiziksel aktivite önerilerini karşlayabilirler ancak yine de günde 8 saatten fazla oturabilirler5. Sağlıklı genç bireylerin fiziksel aktivite düzeylerindeki azalmadan kaynaklı, kognitif durumlarında bozulma, duygu durumlarında değişiklikler ve yaşam kalitelerinde azalma görülmektedir6́

Egzersizin bilişsel işlevle ilişkili olduğu bilinmektedir, ancak etkisi egzersiz türüne ve metodolojiye bağlı olarak değişir. Düzenli aerobik egzersiz, sağllklı yetişkinlerde on yıldan fazla bir süre ile beyin hemodinamiğinde yaşa bağlı azalmayı hafifletmektedir. 
Egzersiz, frontal korteksin oksihemoglobin seviyesini arttırır ve bilişte avantajları artırır7 . Orta yoğunluktaki egzersizin bir başka potansiyel yararı olumlu bir duygu durum değişikliğidir. Düzenli yapılan egzersiz ile hem bilişsel işlevlerdeki hem de duygu durumundaki değişikliklerin yaşam kalitesini de olumlu yönde etkileyeceği öngörülmektedir ${ }^{8}$.

Yapılan çalışmalar kardiyovasküler egzersiz, kuvvet egzersizleri, denge egzersizleri ve esneklik egzersizlerini içermektedir. Ancak, hangi egzersiz türünün bilişi etkilediği hala bilinmemektedir9. Denge performansına bağlı egzersiz, insanın bireysel veya sistemini geliştirdiği için önemlidir. Örneğin, postüral görevler sırasında duyusal sistemi zorlamak, işlevsel duyusal girdileri tekrar gözden geçirerek denge yeteneğini arttırmaktadır ${ }^{10}$. Sağlıklı yetişkinlerde yapılan denge egzersizi çalışmasında denge için, verilen eğitimin kognitif işlevleri, özellikle hafıza ve mekânsal kognisyonu geliştirdiğini göstermektedir ${ }^{11}$.Son zamanlardaki çalışmalarda, fiziksel egzersizin beyin fonksiyonu üzerindeki güçlü etkisinin yanı sıra, bilişsel eğitim ile birleştirildiğinde olumlu etkileri artırabileceği vurgulanmaktadır ${ }^{12,13}$. Bu çalışmanın amacı sağlıklı genç bireylerde kognitif görevle yapılan egzersizlerinin, kognitif durum, duygu durumu ve yaşam kalitesine etkilerini incelemektir.

\section{Gereç ve Yöntem}

\section{Araştırma Yeri, Zamanı ve Örneklem Seçimi}

Bu çalışma, Ekim 2018 - Ekim 2019 tarihleri arasında gerçekleştirilmiştir. İstanbul Medipol Üniversitesi Girişimsel Olmayan Klinik Araştırmalar Etik Kurulu Başkanlığı’nın 25.10.2018 tarih, 10840098- 604.01.01-E.47332 sayılı etik kurulu onayı alınmıştır

Çalışmaya 18-30 yaş arası, araştırmaya dâhil edilme kriterlerine uyan ve katılmaya gönüllü olan 50 sağlıklı genç birey dâhil edildi. Çalışmaya katılan bireylere çalışmanın amacı, yapılacak değerlendirmeler ve egzersiz programı hakkında bilgi verildi. Bireylerden araştırmaya gönüllü olarak kendi rızalarıyla katıldıklarına dair imzalı onam formu alındı.

18-30 yaş aralığında sağlıklı bir birey olmak, çalışmaya devam edebilirlik ve gönüllülük, Türkçe konuşma ve anlama problemi olmaması dâhil edilme kriterleriydi. Sistemik ve nörolojik problemi olmak, renk körü olmak, egzersiz programına düzenli devam etmemek, en az üst üste 3 kez egzersiz programını aksatmak, çalışma süresi boyunca 
herhangi bir muskuloskeletal yaralanma geçirmiş olmak çalışmadan dışlanma kriterleriydi.

\section{Araştırmanın Genel Planı ve Değerlendirmeler}

\section{Egzersiz Protokolü}

Egzersiz grubundaki sağlıklı genç bireyler $30 \mathrm{dk}$ orta şiddette yürüme egzersizi ve denge egzersizlerini uyguladı. Katılımcılara Dünya Sağlı Örgütü'nün orta şiddetli egzersiz tanımına uygun olacak şekilde; 'orta şiddetli egzersiz sırasında bireyin konuşabilecek fakat şarkı söyleyemeyecek şekilde bir tempo ile yürümesi gerektiği’ bilgisi verildi ${ }^{14}$.

Propriosepsiyon hissi ve denge için Thera Band $®$ denge tahtasında çalışıldı. Denge egzersizleri; 30 sn ayaklar bitişik statik durma, 30 sn tek ayak üzerinde durma, 30 sn tandem pozisyonunda durma ve 30 sn parmak ucunda yükselme, Thera Band $囚$ denge tahtasında tek ayak üzerinde çok yönlü uzanma, Thera Band $®$ denge tahtasında, tek ayak üzerinde çok yönlü uzanma egzersizlerini içermekteydi.

\section{Kognitif Görev}

Katılımclardan egzersizler sırasında verilen kognitif görevleri de yerine getirmeleri istendi. Kognitif görevler rastgele kelime üretme, 1'den 20’ye kadar ve 20'den geriye sayma, haftanın günlerini ileri ve geri sayma, yllın aylarını ileri ve geri sayma, 1'den 100'e kadar 7 ekleyerek ve 100'den geriye 7 çlkartarak sayma görevlerini içeriyordu.

\section{Değerlendirmeler}

Tüm katılımcılar egzersiz öncesinde ve egzersiz sonrasında kognitif durum, duygu durumu ve yaşam kalitesi açısından değerlendirildi.

Kognitif durum; Stroop Testi, Sözel Akıcılık Testi ve Sayı Menzili Testi ile değerlendirildi. Stroop Testi işleme hızını, alışılmış davranışı baskılama yeteneğini, odaklanmış dikkati, olağan dışı davranışlar yapma yeteneğini, değişen taleplere göre algısal düzeneği değiştirme yeteneğini ölçmektedir ${ }^{15}$. Sözel Akıcılık Testi sözel üretimin hızı ve kolaylı̆̆ını ölçmeye yarayan ve yürütücü işlevleri değerlendirmede kullanılan testlerden biridir. Testler meyve-isim çiftleri, fonemik ve semantik akıcılık olmak üzere üç çeşit alt değerlendirme ile ölçülmektedir ${ }^{16}$. Sayı Menzili Testi bütünsel dikkatin değerlendirilmesi amacıyla geliştirilmiştir. İleri ve geri sayı menzili alt testlerini içermektedir. İleri sayı menzili testi ile dikkatin sürdürülmesi ölçülürken, geri sayı 
menzili testi ile çalışma belleği ve dikkatin sürdürülmesine bağlı olarak impulsu yönlendirme yeteneği değerlendirilmektedir ${ }^{17}$.

Duygu durumu Depresyon Anksiyete Stres Ölçeği (DASÖ) ile değerlendirildi. DASÖ mental sağlık durumunu değerlendirmek için sıklıkla kullanılan bir ölçektir. DASÖ depresyon, stres ve anksiyetenin semptomlarının ayrıştırılması, bu üç temel kavramla ilgili olumsuz duygusal durumların değerlendirilebilmesi amacıyla kullanılmaktadır ${ }^{18}$.

Yaşam kalitesi Kısa Form -36 (SF-36) ile değerlendirildi. Bu anket genel bir sağlık taraması anketidir. Sorular 8 farklı sağlık alt grubunu inceler. Ayrıca hastanın hastalık hakkında algıladığ

\section{Verilerin İstatistiksel Olarak Değerlendirilmesi}

İstatistiksel analiz için "Statistical Package for Social Science (SPSS) 22.0 for Windows" programı kullanıldı. Verilerin normal dağılımı Shapiro Wilk Test ile değerlendirildi. Veriler normal dağılım göstermediği için grup içi veri değerlendirmeleri Wilcoxon Testi, gruplar arası veri değerlendirmeleri Mann-Whitney U Testi kullanılarak yapıldı. Analizlerde istatistiksel olarak anlamlılık değeri tüm testler için $\mathrm{p} \leq 0,05$ olarak kabul edildi.

\section{Bulgular}

Çalışmaya dâhil edilen 50 bireyin 26'sı kadın, 24’i erkekti. Grup 1'deki bireylerin yaş

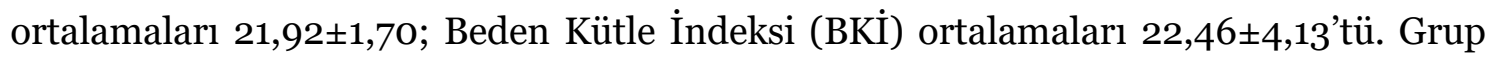
2'deki bireylerin yaş ortalamaları ise 22,40 $\pm 2,78$; BKİ ortalamaları 19,94 $\pm 3,19$ 'du. Bireylerin dominant hemisferleri homojen dağllım göstermekteydi. Grup 1'deki 25 bireyin 20’si düzenli bir egzersiz yapmadıklarını, 5’i düzenli bir egzersiz yaptığını belirtmiştir. Grup II'deki 25 bireyin 20’si düzenli bir egzersiz yapmadıklarını, 5’i düzenli bir egzersiz yaptığını belirtmiştir (Tablo 1). 
Tablo 1. Demografik Veri Bulguları

\begin{tabular}{|c|c|c|c|}
\hline & & $\begin{array}{l}\text { Grup } 1 \\
(n=25)\end{array}$ & $\begin{array}{l}\text { Grup } 2 \\
(n=25)\end{array}$ \\
\hline \multicolumn{2}{|l|}{ Yaş (Ort \pm Ss) } & $21,92 \pm 1,70$ & $22,40 \pm 2,78$ \\
\hline \multicolumn{2}{|l|}{ BKÍ (Ort \pm Ss) } & $22,46 \pm 4,13$ & $19,94 \pm 3,19$ \\
\hline \multirow[t]{2}{*}{ Cinsiyet (n / \%) } & Kadın & $12 /(\% 48)$ & $14 /(\% 56)$ \\
\hline & Erkek & $13 /(\% 52)$ & 11 / (\%44) \\
\hline \multirow[t]{2}{*}{ Dominant hemisfer (n / \%) } & Săg & $4 /(\% 16)$ & $4 /(\% 16)$ \\
\hline & Sol & $21 /(\% 84)$ & $21 /(\% 84)$ \\
\hline \multirow[t]{2}{*}{ Fiziksel Egzersiz (n / \%) } & Evet & $5 /(\% 20)$ & $5 /(\% 20)$ \\
\hline & Hayır & $20 /(\% 80)$ & $20 /(\% 80)$ \\
\hline
\end{tabular}

n: kişi sayısı; Ort: Ortalama; Ss: Standart Sapma

Egzersiz öncesi ve sonrası değerlendirmelerde Grup 1'deki bireylerin İleri ve Geri Sayı Menzili, Sözel Akıcllı, Stroop Test ve SF-36 mental sağllk alt parametresinde istatistiksel olarak anlamlı fark bulundu ( $<<0,05)$. Grup 2'deki bireylerin İleri ve Geri Sayı Menzili, Sözel Akıcılık, Stroop Test ve DASÖ depresyon alt parametresinde istatistiksel olarak anlamlı fark bulundu ( $<<0,05)$ (Tablo 2).

Tablo 2. Grup İçi Verilerin Değerlendirilmesi

\begin{tabular}{|c|c|c|c|c|c|c|}
\hline & \multicolumn{2}{|c|}{ Grup $1(n=25)$} & \multirow[b]{2}{*}{$\begin{array}{c}\text { p } \\
\text { de } \breve{g e r i}\end{array}$} & \multicolumn{2}{|c|}{ Grup $2(n=25)$} & \multirow[b]{2}{*}{$\begin{array}{c}\text { p } \\
\text { değeri }\end{array}$} \\
\hline & $\begin{array}{c}\text { Egzersiz } \\
\text { Öncesi } \\
\text { (Ort } \pm \text { Ss) }\end{array}$ & $\begin{array}{c}\text { Egzersiz } \\
\text { Sonrasi } \\
\text { (Ort } \pm \text { Ss) }\end{array}$ & & $\begin{array}{c}\text { Egzersiz } \\
\text { Öncesi } \\
\text { (Ort } \pm \text { Ss) }\end{array}$ & $\begin{array}{c}\text { Egzersiz } \\
\text { Sonrası } \\
\text { (Ort } \pm \text { Ss) }\end{array}$ & \\
\hline $\begin{array}{l}\text { İleri sayı } \\
\text { menzili }\end{array}$ & $6,24 \pm 1,09$ & $6,92 \pm 1,07$ & $0,004^{*}$ & $6,40 \pm 1,38$ & $7,08 \pm 0,99$ & $\mathbf{0 , 0 0 2 *}$ \\
\hline $\begin{array}{l}\text { Geri sayı } \\
\text { menzili }\end{array}$ & $4,64 \pm 1,25$ & $5,80 \pm 1,08$ & $\mathbf{0 , 0 0 0} *$ & $5,24 \pm 1,05$ & $5,88 \pm 0,97$ & $\mathbf{0 , 0 0 2} *$ \\
\hline
\end{tabular}




\begin{tabular}{|c|c|c|c|c|c|c|}
\hline $\begin{array}{l}\text { Sözel } \\
\text { akıcılık } \\
\text { meyve- } \\
\text { isim çifti }\end{array}$ & $10,00 \pm 1,80$ & $13,04 \pm 1,83$ & $\mathbf{0 , 0 0 0}{ }^{*}$ & $11,00 \pm 2,59$ & $\begin{array}{c}13,00 \pm \\
3,45\end{array}$ & $\mathbf{0 , 0 0 0} *$ \\
\hline $\begin{array}{l}\text { Sözel } \\
\text { akıcılık } \\
\text { semantik }\end{array}$ & $22,40 \pm 5,48$ & $27,20 \pm 5,64$ & $\mathbf{0 , 0 0 1} *$ & $22,80 \pm 6,27$ & $\begin{array}{c}26,28 \pm \\
6,53\end{array}$ & $\mathbf{0 , 0 0 1} *$ \\
\hline $\begin{array}{l}\text { Sözel } \\
\text { akıcılık } \\
\text { fonemik }\end{array}$ & $44,96 \pm 12,50$ & $58,24 \pm 14,97$ & $\mathbf{0 , 0 0 0} *$ & $46,12 \pm 13,2$ & $53,64 \pm 12,12$ & $\mathbf{0 , 0 0 5}{ }^{*}$ \\
\hline $\begin{array}{l}\text { Stroop } \\
\text { Testi }\end{array}$ & $34,32 \pm 10,91$ & $27,72 \pm 10,87$ & o, о00* & $30,92 \pm 6,61$ & $25,12 \pm 6,40$ & $\mathbf{0 , 0 0 1} *$ \\
\hline $\begin{array}{l}\text { DASÖ } \\
\text { depresyon }\end{array}$ & $1,64 \pm 0,90$ & $1,56 \pm 0,86$ & 0,608 & $2,08 \pm 1,11$ & $1,72 \pm 0,84$ & $0,048^{*}$ \\
\hline $\begin{array}{l}\text { DASÖ } \\
\text { stres }\end{array}$ & $2,32 \pm 1,18$ & $2,16 \pm 1,17$ & 0,377 & $1,76 \pm 0,96$ & $1,68 \pm 0,85$ & 0,480 \\
\hline $\begin{array}{l}\text { DASÖ } \\
\text { Anksiyete }\end{array}$ & $2,04 \pm 0,93$ & $1,92 \pm 0,95$ & 0,405 & $1,96 \pm 1,24$ & $1,80 \pm 1,00$ & 0,157 \\
\hline $\begin{array}{l}\text { SF-36 } \\
\text { mental } \\
\text { sağlık }\end{array}$ & $45,32 \pm 41,85$ & $62,96 \pm 41,30$ & $\mathbf{0 , 0 5 0 ^ { * }}$ & $\begin{array}{c}52,00 \\
\pm 38,65\end{array}$ & $\begin{array}{c}46,60 \pm \\
34,78\end{array}$ & 0,394 \\
\hline $\begin{array}{l}\text { SF-36 } \\
\text { fiziksel } \\
\text { sağlık }\end{array}$ & $83,00 \pm 23,62$ & $90,68 \pm 16,35$ & 0,107 & $\begin{array}{c}65,36 \pm \\
35,89\end{array}$ & $\begin{array}{c}74,00 \pm \\
34,97\end{array}$ & 0,172 \\
\hline
\end{tabular}

n: kişi sayısı; Ort: Ortalama; Ss: Standart Sapma, * $\mathrm{p} \leq 0.05$

Egzersiz öncesi veriler karşılaştırıldığında gruplar arasında fark olmadığı görüldü (p>0,05). Egzersiz sonrası fark verilerinde; Sözel Akıcılık Testi fonemik alt parametresinde ve SF-36 mental sağlık alt parametresinde Grup 1 lehine istatistiksel olarak anlamlı fark olduğu bulundu (p<0,05) (Tablo 3). 
Tablo 3. Gruplar Arası Verilerin Değerlendirilmesi

\begin{tabular}{|c|c|c|c|c|c|c|c|}
\hline & \multicolumn{3}{|c|}{ Egzersiz Öncesi } & \multicolumn{3}{|c|}{ Egzersiz Sonrası } & \multirow[b]{2}{*}{$\begin{array}{c}\text { Fark } \\
\quad \mathbf{p}\end{array}$} \\
\hline & $\begin{array}{c}\text { Grup } 1 \\
(n=25) \\
(\text { Ort } \pm \text { Ss) }\end{array}$ & $\begin{array}{c}\text { Grup 2 } \\
(n=25) \\
(\text { Ort } \pm \text { Ss })\end{array}$ & $\mathbf{p}$ & $\begin{array}{c}\text { Grup } 1 \\
(n=25) \\
(\text { Ort } \pm \text { Ss })\end{array}$ & $\begin{array}{c}\text { Grup } 2 \\
(n=25) \\
(\text { Ort } \pm \text { Ss })\end{array}$ & $\mathbf{p}$ & \\
\hline $\begin{array}{l}\text { Íleri sayı } \\
\text { menzili }\end{array}$ & $6,24 \pm 1,09$ & $6,40 \pm 1,38$ & 0,549 & $6,92 \pm 1,07$ & $7,08 \pm 0,99$ & 0,063 & o,877 \\
\hline $\begin{array}{l}\text { Geri sayı } \\
\text { menzili }\end{array}$ & $4,64 \pm 1,25$ & $5,24 \pm 1,05$ & 0,071 & $5,80 \pm 1,08$ & $5,88 \pm 0,97$ & 0,830 & 0,071 \\
\hline $\begin{array}{l}\text { Sözel } \\
\text { akıcılık } \\
\text { meyve- } \\
\text { isim çifti }\end{array}$ & $10,0 \pm 1,80$ & $11,0 \pm 2,59$ & 0,239 & $13,04 \pm 1,83$ & $13,00 \pm 3,45$ & 0,644 & 0,062 \\
\hline $\begin{array}{l}\text { Sözel } \\
\text { akıcılık } \\
\text { semantik }\end{array}$ & $22,40 \pm 5,48$ & $22,80 \pm 6,27$ & 0,620 & $27,20 \pm 5,64$ & $26,28 \pm 6,53$ & 0,648 & 0,533 \\
\hline $\begin{array}{l}\text { Sözel } \\
\text { akıcılık } \\
\text { fonemik }\end{array}$ & $44,96 \pm 12,50$ & $46,12 \pm 13,2$ & 0,727 & $58,24 \pm 14,97$ & $53,64 \pm 12,12$ & 0,620 & o,o39* \\
\hline $\begin{array}{l}\text { Stroop } \\
\text { Testi }\end{array}$ & $34,32 \pm 10,91$ & $30,92 \pm 6,61$ & 0,376 & $27,72 \pm 10,87$ & $25,12 \pm 6,40$ & 0,512 & 0,627 \\
\hline $\begin{array}{l}\text { DASÖ } \\
\text { depresyon }\end{array}$ & $1,64 \pm 0,90$ & $2,08 \pm 1,11$ & 0,136 & $1,56 \pm 0,86$ & $1,72 \pm 0,84$ & 0,416 & 0,285 \\
\hline $\begin{array}{l}\text { DASÖ } \\
\text { stres }\end{array}$ & $2,32 \pm 1,18$ & $1,76 \pm 0,96$ & 0,082 & $2,16 \pm 1,17$ & $1,68 \pm 0,85$ & 0,144 & 0,814 \\
\hline $\begin{array}{l}\text { DASÖ } \\
\text { Anksiyete }\end{array}$ & $2,04 \pm 0,93$ & $1,96 \pm 1,24$ & 0,435 & $1,92 \pm 0,95$ & $1,80 \pm 1,00$ & 0,588 & 0,716 \\
\hline $\begin{array}{l}\text { SF-36 } \\
\text { mental } \\
\text { sağlık }\end{array}$ & $45,32 \pm 41,85$ & $52,00 \pm 38,65$ & 0,547 & $62,96 \pm 41,30$ & $46,60 \pm 34,78$ & 0,130 & $\mathbf{0 , 0 2 7} 7^{*}$ \\
\hline $\begin{array}{l}\text { SF-36 } \\
\text { fiziksel } \\
\text { sağlık }\end{array}$ & $83,00 \pm 23,62$ & $65,36 \pm 35,89$ & 0,062 & $90,68 \pm 16,35$ & $74,00 \pm 34,97$ & 0,096 & 0,971 \\
\hline
\end{tabular}

n: kişi sayısı; Ort: Ortalama; Ss: Standart Sapma, * $\mathrm{p} \leq 0.05$ 


\section{Tartıșma}

Fiziksel aktivite, enerji harcaması gerektiren iskelet kası tarafından üretilen herhangi bir bedensel hareket ve fiziksel aktivitenin bir alt kümesi olan "egzersiz" olarak tanımlanmaktadır. Egzersiz ise, fiziksel uygunluğun bileşenlerini sürdürmeyi veya iyileştirmeyi amaçlayan planlı, yapılandırılmış ve tekrarlanan bir davranışı içerir ${ }^{20}$. Son çağlarda yaşam koşullarının değişmesiyle birlikte, özellikle genç bireyler sedanter yaşam tarzına geçiş yapmış ve fiziksel olarak inaktif hale gelmiştir. Fiziksel hareketsizlik terimi, yetersiz miktarlarda orta ila kuvvetli yoğunluk aktivitesinin gerçekleştirilmesini ifade eder (yani, belirli fiziksel aktivite kurallarına uymamak) ${ }^{21}$. Fiziksel inaktiviteyi, fiziksel hareketsizlik perspektifinden ele alan araştırmacılar, "Çok fazla oturma”yı, egzersiz eksikliği ile bağlantılı olarak metabolizma üzerinde farklı sağlık tehlikelerine yol açan önemli bir yerleşik davranış olarak vurgulamıştır ${ }^{22}$. Bilişsel görevleri (zihinsel çalışma) içeren yerleşik davranışların ise, çok düşük hareket ve nörojenik stresin bir bileşeni ile düşük aktivite profiline sahip olduğu bildirilmiştir²3.

Sedanter davranışın, bireyin mevcut fiziksel aktivite yönergelerini karşılasa bile, fiziksel hareketsizliğin bir belirleyicisi olduğu ileri sürülmüştür ${ }^{24}$. Fiziksel hareketsizlik ve hareketsiz olma yaygınlığının artması, insanları artan hastalık riskine yatkın kılmaktadır25. Sağlıklı genç bireylerde kognitif fonksiyonlarda ve duygu durumunda meydana gelen değişiklikler yaşam kalitelerini de etkilemektedir. Psikolojik esneklik, fiziksel aktivitenin potansiyel bir öngörücüsü, bir bireyin olumsuz özel olaylara dayanma istekliliğini ve değerlerine göre yaşama yeteneğini yansıtmaktadır²6. Ek olarak, fiziksel olarak aktif yetişkinlerin, fiziksel olarak daha az aktif yetişkinlerden daha iyi farkındalık becerileri (psikolojik esnekliğin bir bileşeni) gösterdiği bildirilmektedir ${ }^{27}$. Depresyon, fiziksel hareketsizlik ve hareketsiz davranış gibi sağlıksız davranışlarla da ilişkilidir²8. Stres ise fiziksel aktivitenin önemli bir belirleyicisi olabilir. Prospektif çalışmalar, psikolojik stresin daha az fiziksel aktivite/egzersiz veya daha hareketsiz davranış öngördügünü göstermektedir ${ }^{29}$. Tüm bu olumsuzluklar ise yaşam kalitesini etkilemektedir.

Dünya Sağlık Örgütü, 18 yaş ve üzerindeki yetişkinlerin haftada en az 150 dakikalık orta ila güçlü aktiviteye veya 30 dakikalık günlük aktiviteye eşdeğer olmasını tavsiye etmektedir ${ }^{14}$. Aerobik egzersiz, yürütücü işlevler gibi karmaşık bilişsel yetenekler için özellikle yararlı görünmektedir. Örneğin, inhibitör kontrol ve dikkatin kontrolünün kısa 
süreli aerobik egzersiz antrenmanlarından faydalandığı gösterilmiştir ${ }^{30}$. Sadece orta şiddette aerobik egzersize odaklanan bir meta-analizde, çocuk örneklerinden yaşlı erişkinlere kadar yürütücü işlev üzerinde olumlu etkiler bulunmuştur ${ }^{31}$. Aerobik egzersizin bir başka potansiyel yararı olumlu bir duygu durum değişikliğidir ${ }^{\circ}$. Düşük ve orta yoğunluklu egzersiz genellikle olumlu duygu durum değişiklikleri ile ilişkilendirilmektedir. Egzersiz süresinin, duygu durum değişiklikleri üzerindeki etkilerinin yönünü ve kapsamını etkilediği de ileri sürülmüştür32. Bazı çalışmalar 7-60 dakikalık egzersiz süresinin, duygu durumunu iyileştirebileceğini düşündürse de, önceki çalışmaların çoğu 20-40 dakikalık egzersiz seanslarının duygu durum değişiklikleri üzerindeki etkilerini vurgulamıştır33,34. Bu çalışmada literatüre uygun olarak 40 dakikalık seanslar şeklinde haftada 3 gün, günde 1 seans olmak üzere 6 hafta boyunca sağlıklı genç bireylere aerobik ve denge egzersizlerinin kombinasyonundan oluşan yapılandırılmış bir egzersiz programı uygulanmıştır. Sağlıklı genç bireylerde 6 hafta boyunca yapılan düzenli egzersizin, kognitif durum ve duygu durumu üzerinde etkili olduğu sonucuna ulaşılmıştır. Sağlıklı genç bireylerin gelişen teknoloji çağıyla birlikte ortaya çıkan sedanter yaşam tarzından ayrılarak, 6 hafta boyunca düzenli bir şekilde egzersiz yapmalarının, beynin hemoglobin düzeyini arttırdığı ve bu durumun kognitif fonksiyonlara ve duygu durumuna olumlu şekilde yansıdığı düşünülmektedir.

Düzenli yapılan fiziksel egzersiz, hipokampusun dentat girusundaki yeni nöronların çoğalmasını teşvik ederken, kognitif eğitim ağdaki bu yeni nöronların hayatta kalmasını ve entegrasyonunu sağlayarak, bu sinerjik yolların hipokampal işlevi geliştirdiğini düşündürmektedir35. Bu nedenle, fiziksel ve kognitif egzersizi birleştiren bir müdahalenin hipokampal fonksiyon üzerinde tek başına egzersizden daha fazla etkisi olabileceği öngörülmektedir ${ }^{36}$. Bu öngörüye uygun olarak yapılan bir çalışmada, 6 haftalık orta yoğunluklu aralıklı aerobik egzersiz uygulayan genç yetişkinlerin, yürütücü işlev ve bellek görevlerinde iyileşme olduğu görülmüştür. Bu çalışmada kognitif görevle kombine yapılan egzersizin genel kognitif performansı iyileştirdiği sonucuna ulaşılmaktadır. Kognitif eğitimin bireylerin duygu durumu üzerinde etkili olduğu son zamanlardaki çalışmalarda belirtilmektedir37. Bu çalışmada kognitif görevle yapılan egzersizin bireylerin DASÖ depresyon alt parametresinde anlamlı iyileşmeye neden olduğu sonucuna ulaşılmıştır. Bu durumun duygu durumunun da kognitif görevle yapılan egzersizlerin etkilediği frontal bölgeden yönetiliyor olmasından kaynaklandığı düşünülmektedir. 
Kognitif görevle yapılan ve yapılmayan aerobik ve denge egzersizlerini karşılaştırdığımızda, kognitif testlerden sözel akıcılık testinde ve yaşam kalitesinin mental sağlık alt parametresinde iyileşme olduğu sonucuna ulaşılmıştır. Yapılan çalışmalarda da belirtildiği üzere, kognitif görevle yapılan egzersizlerin özellikle hipokampal alan üzerinde etkili olmasından kaynaklı özellikle sözel akıcılık testinde anlamlı düzeyde bir artış olduğunu düşünülmektedir. Yaşam kalitesi ile kognitif fonksiyonlar arasında bir ilişki olduğu çalışmalarda vurgulanmaktadır38,39. Bu çalışmada kognitif görevle yapılan fiziksel egzersizin sağlıklı genç bireylerde yaşam kalitesinin özellikle mental sağlık alt parametresinde olumlu etkisi olduğunu görülmüştür. Kognitif fonksiyonlar ile yaşam kalitesi arasındaki ilişkinin bu sonucu etkilediği görüşündeyiz.

\section{Limitasyonlar}

Katılımcıların fiziksel aktivite düzeyleri demografik veri formunda evet/hayır şeklinde sorgulanması ve objektif sonuç veren akselerometre kullanılmaması ve egzersizin ve kognitif görevin beyindeki aktiflendiği düşünülen alanlar üzerindeki etkisinin objektif olarak değerlendirilmemiş olması çalışmanın limitasyonlarını oluşturmaktadır.

\section{Sonuç}

Sağlıklı genç bireylerde, hem egzersiz hem de kognitif görevle yapılan egzersizlerin kognitif fonksiyonlar üzerinde etkili olduğu görüldü. Kognitif görevle yapılan egzersizlerin sağlıklı genç bireylerin kognitif durum ve yaşam kaliteleri üzerinde etkili olduğu sonucuna ulaşıldı. Uygulanan egzersizlerin sağlıklı genç bireylerde özellikle kognisyon ve duygu durumu üzerine etkisinin daha iyi anlaşllabilmesi için, objektif nitelikteki çalışmalara ihtiyaç duyulduğu düşünülmektedir.

\section{KAYNAKLAR}

1. Barnett, LM, Van Beurden E, Morgan PJ, Brooks LO, Beard JR. Childhood motor skill proficiency as a predictor of adolescent physical activity. Journal of Adolescent Health. 2009;44(3):252-259. doi: 10.1016/j.jadohealth.2008.07.004. 
2. Matthews CE, Chen KY, Freedson PS, et al. Amount of time spent in sedentary behaviors in the United States, 2003-2004. American Journal of Epidemiology. 2008;167(7):875-881. doi: 10.1093/aje/kwm390.

3. Mutikainen S, Föhr T, Karhunen L, et al. Predictors of increase in physical activity during a 6-month follow-up period among overweight and physically inactive healthy young adults. Journal of Exercise Science \& Fitness. 2015;13(2):63-71. doi:10.1016/j.jesf.2015.05.001.

4. Hallal PC, Andersen LB, Bull FC, Guthold R, Haskell W, Ekelund. Lancet Physical Activity Series Working Group. Global physical activity levels: surveillance progress, pitfalls, and prospects. The Lancet. 2012;380(9838):247257. doi: 10.1016/So140-6736(12)60646-1.

5. Heffernan KS, Tarzia BJ, Kasprowicz AG, Lefferts WK, Hatanaka M, Jae SY. Self-reported sitting time is associated with higher pressure from wave reflections independent of physical activity levels in healthy young adults. American Journal of Hypertension. 2013;26(8):1017-1023. doi: 10.1093/ajh/hpto53.

6. Pereira SMP, Li L, Power C. Lifetime risk factors for leisure-time physical inactivity in mid-adulthood. Preventive Medicine Reports. 2018;11:23-30. doi:10.1016/j.pmedr.2018.05.005.

7. Kato K, Iwamoto K, Kawano N, Noda Y, Ozaki N, Noda A. Differential effects of physical activity and sleep duration on cognitive function in young adults. Journal of Sport and Health Science. 2018;7(2):227-236. doi: 10.1016/j.jshs.2017.01.005.

8. Stenling A, Moylan A, Fulton E, Machado L. Effects of a brief stair-climbing intervention on cognitive performance and mood states in healthy young adults. Frontiers in Psychology. 2019;10:2300-2312.

9. Lauenroth A, Ioannidis AE, Teichmann B. Influence of combined physical and cognitive training on cognition: a systematic review. BMC Geriatrics. 2016;16(1):141-156. doi: 10.1093/geront/gnv549.11. 
10. Prasertsakul T, Kaimuk P, Chinjenpradit W, Limroongreungrat W, Charoensuk W. The effect of virtual reality-based balance training on motor learning and postural control in healthy adults: a randomized preliminary study. Biomedical Engineering Online. 2018;17(1):124-141. doi: 10.1186/s12938-018-0550-0.

11. Rogge AK, Röder B, Zech A, et al. Balance training improves memory and spatial cognition in healthy adults. Scientific Reports. 2017;7(1):1-10. doi: 10.1038/s41598-017-06071-9.

12. Heisz JJ, Clark IB, Bonin $\mathrm{K}$, et al. The effects of physical exercise and cognitive training on memory and neurotrophic factors. Journal of Cognitive Neuroscience. 2017;29(11):1895-1907.doi: 10.1162/jocn_a_01164.

13. Heisz JJ, Gould M, McIntosh AR. Age-related shift in neural complexity related to task performance and physical activity. Journal of Cognitive Neuroscience. 2015;27(3):605-613. doi: 10.1162/jocn_a_00725.

14. World Health Organization. Global recommendations on physical activity for health.https://apps.who.int/iris/bitstream/handle/10665/44399/97892415999 79 eng.pdf?sequence=1. Yayınlanma Tarihi 2010. Erişim Tarihi 27 Mayıs 2020.

15. MacLeod CM. Half a century of research on the Stroop effect: an integrative review. Psychological Bulletin. 1991;109(2):163-203. doi: 10.1037/o0332909.109.2.163.

16. Piatt AL, Fields JA, Paolo AM, Tröster AI. Action (verb naming) fluency as an executive function measure: convergent and divergent evidence of validity. Neuropsychologia. 1999;37(13):1499-1503. doi: 10.1016/Soo283932(99)00066-4.

17. Kurt P, Yener G, Oguz M. Impaired digit span can predict further cognitive decline in older people with subjective memory complaint: a preliminary result. Aging \& Mental Health. 2011;15(3):364-369. doi: 10.1080/13607863.2010.536133.

18. Akin A, Çetin B. The depression anxiety and stress scale (DASS): the study of validity and reliability. Educational Sciences: Theory \& Practice. 2007;7(1):241268. doi: 10.13189/ujer.2016.041202. 
19. Brazier JE, Harper R, Jones NM, et al. Validating the SF-36 health survey questionnaire: new outcome measure for primary care. $\mathrm{Bmj}$. 1992;305(6846):16o-164. doi: 10.1136/bmj.305.6846.16o.

20. González K, Fuentes J, Márquez, JL. Physical inactivity, sedentary behavior and chronic diseases. Korean Journal of Family Medicine. 2017;38(3):111-115. doi: 10.4082/kjfm.2017.38.3.111.

21. Tremblay MS, Aubert S, Barnes JD, et al. Sedentary behavior research network (SBRN)-terminology consensus project process and outcome. International Journal of Behavioral Nutrition and Physical Activity. 2017;14(1):75-92. doi: 10.1186/s12966-017-0525-8.

22. Owen N, Healy GN, Matthews CE, Dunstan DW. Too much sitting: the population-health science of sedentary behavior. Exercise and Sport Sciences Reviews. 2010;38(3):105-113. doi: 10.1097/JES.obo13e3181e373a2.

23. Thivel D, Tremblay A, Genin PM, Panahi S, Rivière D, Duclos M. Physical activity, inactivity, and sedentary behaviors: definitions and implications in occupational health. Frontiers in Public Health. 2018;6:288-293. doi: 10.3389/fpubh.2018.00288.

24. Booth FW, Lees SJ. Fundamental questions about genes, inactivity, and chronic diseases. Physiological Genomics. 2007;28(2):146-157. doi: 10.1152/physiolgenomics.00174.2006.

25. Patel AV, Bernstein L, Deka A, et al. Leisure time spent sitting in relation to total mortality in a prospective cohort of US adults. Am J Epidemiol. 2010;172:419-29. doi:10.1093/aje/kwq155

26. Kashdan TB, Rottenberg J. Psychological flexibility as a fundamental aspect of health. Clinical Psychology Review. 2010;30(7):865-878. doi: 10.1016/j.cpr.2010.03.001.

27. Ramaci T, Bellini D, Presti G, Santisi G. Psychological flexibility and mindfulness as predictors of individual outcomes in hospital health workers. Frontiers in Psychology. 2019;10:1302-1314. doi: 10.3389/fpsyg.2019.01302. 
28. Jia H, Zack MM, Gottesman II, Thompson WW. Associations of smoking, physical inactivity, heavy drinking, and obesity with quality-adjusted life expectancy among US adults with depression. Value in Health. 2018;21(3):364371. doi: 10.1016/j.jval.2017.08.002.

29. Stults-Kolehmainen MA, Sinha R. The effects of stress on physical activity and exercise. Sports Medicine. 2014;44(1):81-121. doi: 10.1007/s40279-013-0090-5.

30. Stenling A, Moylan A, Fulton E, Machado L. Effects of a brief stair-climbing intervention on cognitive performance and mood states in healthy young adults. Frontiers in Psychology. 2019;10:2300-2312. doi: 10.3389/fpsyg.2019.02300.

31. Ludyga S, Gerber M, Brand S, Holsboer-Trachsler E, Pühse U. Acute effects of moderate aerobic exercise on specific aspects of executive function in different age and fitness groups: A meta-analysis. Psychophysiology. 2016;53(11):16111626. doi: 10.1111/psyp.12736.

32. Berger BG, Darby LA, Zhang Y, Owen DR, Tobar DA. Mood alteration after 15 minutes of preferred intensity exercise: Examining heart rate, perceived exertion, and enjoyment. J. Sport Behav. 2016;39(1):3-21.

33. Reed J, Ones DS. The effect of acute aerobic exercise on positive activated affect: A meta-analysis. Psychology of Sport and Exercise. 2006;7(5):477-514. doi: 10.1016/j.psychsport.2005.11.003.

34. Loy BD, O'Connor PJ, Dishman RK. The effect of a single bout of exercise on energy and fatigue states: a systematic review and meta-analysis. Fatigue: Biomedicine, Health \& Behavior. 2013;1(4):223-242. doi: 10.1080/21641846.2013.843266.

35. Fabel K, Wolf S, Ehninger D, Babu H, Galicia P, Kempermann G. Additive effects of physical exercise and environmental enrichment on adult hippocampal neurogenesis in mice. Frontiers in Neuroscience. 2009;3:1-7. doi: 10.3389/neuro.22.002.2009. 
36. Olsen RK, Moses SN, Riggs L, Ryan JD. The hippocampus supports multiple cognitive processes through relational binding and comparison. Frontiers in Human Neuroscience. 2012;6:146-159. doi: 10.3389/fnhum.2012.00146.

37. Goghari VM, Krzyzanowski D, Yoon S, Dai Y, Toews D. Attitudes and beliefs toward computerized cognitive training in the general population. Frontiers in Psychology. 2020;11:1-11. doi: 10.3389/fpsyg.2020.00503.

38. DeRosse P, Nitzburg GC, Blair M, Malhotra AK. Dimensional symptom severity and global cognitive function predict subjective quality of life in patients with schizophrenia and healthy adults. Schizophrenia Research. 2018;195:385-390. doi: 10.1016/j.schres.2017.10.018.

39. Mendoza-Ruvalcaba NM, Arias-Merino ED. "I am active": effects of a program to promote active aging. Clinical Interventions in Aging. 2015;10:829-837. 